\title{
Changes in germ cell adenylate cyclase and protein carboxyl methylase activities in rat testicular tissue during bilateral cryptorchidism and after orchidopexy
}

\author{
T. Jahnsen*, H. Attramadal*, B. Karpe†, E. M. Ritzen $\ddagger$, and V. Hansson§ \\ *Institute of Pathology, Rikshospitatlet, Oslo 1, Norway; \\ $\dagger$ Department of Pediatric Surgery, St Goran Hospital, 11281 Stockholm, Sweden; \\ $\ddagger$ Pediatric Endocrinology Unit, Karolinska Hospital, 10401 Stockholm, Sweden; and \\ $\S$ Institute of Medical Biochemistry, University of Oslo, Blindern, Oslo 3, Norway
}

\begin{abstract}
Summary. Soluble $\mathrm{Mn}^{2+}$-dependent adenylate cyclase and protein carboxyl methylase are two enzymes that are primarily localized in haploid germ cells of rat testicular tissue, and both enzymes exhibit an increase in activity in association with sexual maturation. Experimental cryptorchidism (surgery at 17 days of age) in immature rats prevented the age-dependent increase in the activity of these two testicular enzymes. After orchidopexy at 34 days of age the activities of these two enzymes increased to normal control values in association with testicular growth. These observations show that biochemical markers such as soluble $\mathrm{Mn}^{2+}$-dependent adenylate cyclase and protein carboxyl methylase can be used to follow germ cell differentiation.
\end{abstract}

\section{Introduction}

Cryptorchidism is associated with impairment of spermatogenesis. Germ cells, Sertoli cells and Leydig cells have all been shown to be functionally damaged during cryptorchidism (Hagenäs \& Ritzen, 1976; Hagenäs, Ritzen, Svensson, Hansson \& Purvis, 1978; de Kretser, Sharpe \& Swanston, 1979; Kerr, Rich \& de Kretser, 1979; Jahnsen, Gordeladze, Haug \& Hansson, 1981). Soluble $\mathrm{Mn}^{2+}$-dependent adenylate cyclase is localized in haploid germ cells (Braun \& Dods, 1975; Cusan, Gordeladze, Parvinen, Clausen \& Hansson, 1981b; Gordeladze, Purvis, Clausen, Rommerts \& Hansson, 1981). We have previously shown that the activity of this enzyme is reduced by $82 \%$ within 3 days of experimental cryptorchidism in adult rats (Jahnsen et al., 1981). Protein carboxyl methylase is another enzyme that is preferentially localized in haploid germ cells (Gagnon, Axelrod, Musto, Dym \& Bardin, 1979), and testis-specific isoenzymes have been described (Cusan, Gordeladze, Andersen \& Hansson, 1981a). In the present study we examined the effect and timerelationship of experimental cryptorchidism and orchidopexy in the rat on these two biochemical markers of haploid germ cells.

\section{Materials and Methods}

\section{Animals}

Seventy-two male Sprague-Dawley rats (6/group) were used at 17 days of age: rats in 4 groups were subjected to sham operations, rats in 7 groups were made bilaterally cryptorchid and those in the final group were killed at the beginning of the experiment. At 34 days of age one sham-operated and one bilaterally cryptorchid group of rats were killed. Simultaneously, 3 groups of control rats 
and 3 cryptorchid groups were sham operated, whereas the remaining 3 groups of rats were surgically treated by orchidopexy. At 42,59 and 120 days of age, one group each of control, cryptorchid and surgically treated rats with orchidopexy was killed. Surgical techniques and treatment of the animals have been described previously (Karpe, Plöen, Hagenäs \& Ritzen, 1981). The testes were weighed, frozen and stored at $-70^{\circ} \mathrm{C}$ until assayed for soluble $\mathrm{Mn}^{2+}$-dependent adenylate cyclase and carboxyl methylase activities.

\section{Preparation of cytosol}

Testicular tissue was homogenized in TE buffer (10 mM-Tris- $\mathrm{HCl}, 1 \mathrm{~mm}$ EDTA, pH 7-4). Homogenates were centrifuged at $105000 \mathrm{~g}$ for $1 \mathrm{~h}$ at $0^{\circ} \mathrm{C}$. Supernatants (cytosols) were decanted and stored at $-70^{\circ} \mathrm{C}$ until assayed.

\section{$\mathrm{Mn}^{2+}$-dependent adenylate cyclase assay}

$\mathrm{Mn}^{2+}$-dependent adenylate cyclase (EC 4.6.1.1) activity in $20 \mu$ l cytosol fractions $(30-60 \mu \mathrm{g}$ protein/assay tube) was measured essentially as described by Gordeladze \& Hansson (1980). Cytosols from whole testis tissue were examined for adenylate cyclase activity in a final volume of $50 \mu \mathrm{l}$. Each assay tube contained $1.0 \mathrm{~mm}$-ATP (including $10^{6}$ c.p.m. $\left[\alpha-{ }^{32} \mathrm{P}\right] \mathrm{ATP}$ ), $10 \mathrm{mM}-\mathrm{MnCl}_{2}$, 1 mM-cAMP (including 10000 c.p.m. [8- $\left.{ }^{3} \mathrm{H}\right] \mathrm{cAMP}$ ), $1.4 \mathrm{mM-EDTA}$, and an ATP-regenerating system consisting of creatine phosphate $(20 \mathrm{mM})$, creatine kinase $(0.2 \mathrm{mg} / \mathrm{ml})$ and myokinase $(0.02 \mathrm{mg} / \mathrm{ml})$ in $25 \mathrm{~mm}$ Tris $-\mathrm{HCl}$ buffer, $\mathrm{pH} 7 \cdot 3$. The incubations were carried out at $35^{\circ} \mathrm{C}$ for 20 min. Cyclic AMP was isolated by Dowex and alumina chromatography (Salomon, Londos \& Rodbell, 1974) with the modifications described by Birnbaumer, Yang, Hunzicker-Dunn, Bockaert $\&$ Duran (1976). The sensitivity of the adenylate cyclase assay was $0.5-1 \cdot 0 \mathrm{pmol}$ cAMP formed per $50 \mu$ l volume.

\section{Protein carboxyl methylase assay}

Protein carboxyl methylase (EC 2.1.2.24) activity was assayed by a modification of a method previously described (Axelrod \& Daly, 1965; Kim \& Paik, 1970). Enzyme activity in $10 \mu 1$ cytosol (15-30 $\mu \mathrm{g}$ protein/assay tube) was measured at $35^{\circ} \mathrm{C}$ in $0 \cdot 25 \mathrm{M}$-sodium acetate buffer $(10 \mu \mathrm{l}), \mathrm{pH} 5 \cdot 8$, using $1.6 \mu \mathrm{M}-S$-adenosyl-L-[methyl- ${ }^{3} \mathrm{H}$ ]methionine $(10 \mu \mathrm{l})$ as methyl donor, and gelatin at $10 \mathrm{mg} / \mathrm{ml}$ $(10 \mu \mathrm{l})$ as exogenous methyl acceptor protein (MAP). After a 15-min incubation, the reaction was stopped by the addition of $500 \mu 110 \%$ trichloroacetic acid and centrifuged at $4200 \mathrm{~g}$ for $20 \mathrm{~min}$, and the pellet was resuspended in $200 \mu \mathrm{l} \mathrm{M}$-borate buffer, $\mathrm{pH} 11$, to release the methyl groups. The radioactive methanol was extracted with $3 \mathrm{ml}$ of a mixture of toluene-isoamyl alcohol $(3: 2 \mathrm{v} / \mathrm{v})$. Aliquants of $1 \mathrm{ml}$ were then transferred to two separate vials; one was counted by liquid scintillation spectrometry (LKB, DELTA 300) and the second aliquant (blank) was evaporated for $1 \mathrm{~h}$ at $80^{\circ} \mathrm{C}$ in a chromatography oven before radioactivity was determined. The difference in radioactivity between the two vials was taken as a measure of methanol formation. The results are expressed as pmol $\mathrm{CH}_{3} \mathrm{OH}$ formed per $\mathrm{mg}$ protein per $15 \mathrm{~min}$. The sensitivity of the protein carboxyl methylase assay was $1-2 \mathrm{pmol} \mathrm{CH}_{3} \mathrm{OH}$ formed per assay tube.

\section{Miscellaneous}

The protein content of cytosol fractions was measured by the technique of Lowry, Rosebrough, Farr \& Randall (1951). The ATP concentration used in the adenylate cyclase assay was calculated by u.v.-light spectrophotometry at $260 \mathrm{~nm}$. 


\section{Results}

Cryptorchidism on Day 17 of age prevented the increase in testicular weight which is normally associated with sexual maturation (Fig. 1a). However, after orchidopexy on Day 34 testicular weight increased progressively to approach control values within 3 months.

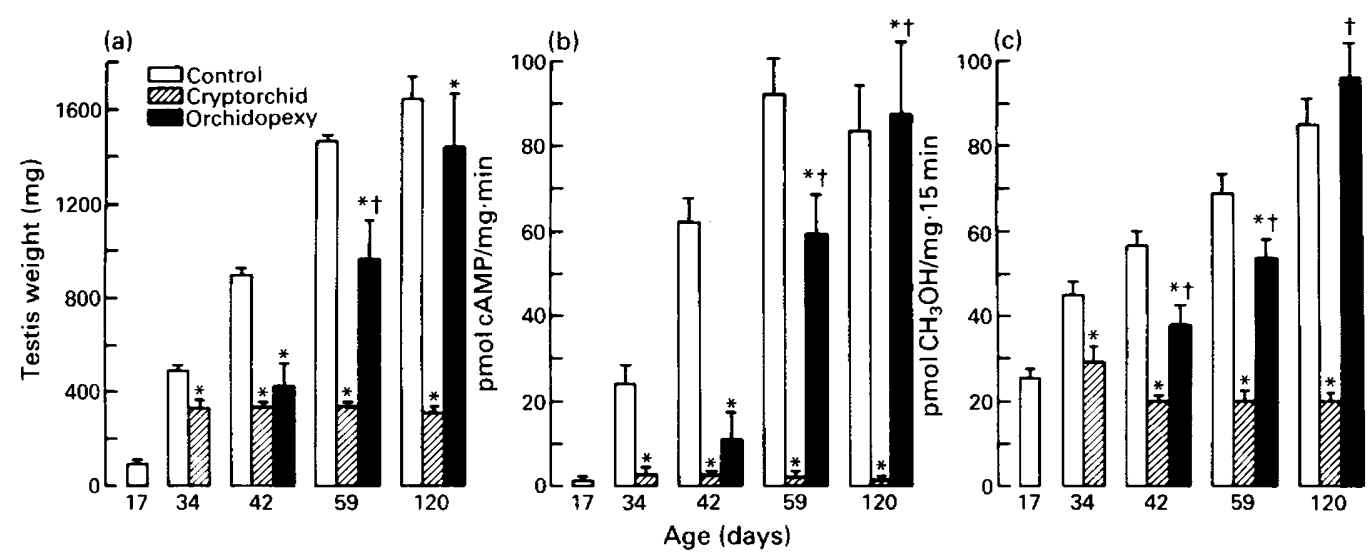

Fig. 1. Changes in (a) testicular weights, (b) soluble $\mathrm{Mn}^{2+}$-dependent adenylate cyclase activity and (c) protein carboxyl methylase activity (mean \pm s.d., $n=6$ ) in control rats, bilaterally cryptorchid rats and rats treated by orchidopexy at 34 days of age. ${ }^{*} P<0.01$ compared with values for controls (Wilcoxon rank test). $\dagger P<0.01$ compared with values for cryptorchid rats (Wilcoxon rank test).

Soluble $\mathrm{Mn}^{2+}$-dependent adenylate cyclase activities in rat testicular tissue were dramatically influenced by cryptorchidism (Fig. 1b). Whereas in control animals there was a rapid and pronounced increase in adenylate cyclase activity from Day 17 to Day 59, enzyme activity in cryptorchid rat testes remained low and unchanged from Days 17 to 120 . Orchidopexy of animals that had been bilaterally cryptorchid from 17 to 34 days of age showed a progressive and marked increase in adenylate cyclase activity, and reached control values within 3 months. Changes in protein carboxyl methylase activities after cryptorchidism and orchidopexy were very similar to those of adenylate cyclase (Fig. 1c).

\section{Discussion}

Soluble $\mathrm{Mn}^{2+}$-dependent adenylate cyclase and protein carboxyl methylase have been characterized in testicular tissue and shown to be preferentially localized in haploid germ cells (Braun \& Dods, 1975; Gagnon et al., 1979; Cusan et al., 1981b; Gordeladze et al., 1981). The possible roles of soluble $\mathrm{Mn}^{2+}$-dependent adenylate cyclase and protein carboxyl methylase in testicular tissue are unknown.

Cryptorchidism is associated with degeneration and loss of germ cells, and this may explain the marked decrease in testicular weight and the activities of $\mathrm{Mn}^{2+}$-dependent adenylate cyclase and protein carboxyl methylase observed in the present study.

The present results show that experimental cryptorchidism induced in the rat at 17 days of age creates damage to the germ cells which can be completely reversed within 2-3 months by orchidopexy at 34 days of age. This is essentially the same conclusion made by Jegou, Peake, Irby \& 
de Kretser (1984), who measured testis weight, seminiferous tubule fluid production and androgenbinding protein (ABP) production in a model similar to that used in the present study. Furthermore, our data show that $\mathrm{Mn}^{2+}$-dependent adenylate cyclase and protein carboxyl methylase are sensitive biochemical markers for germ cell differentiation and development. Measurements of these enzymes may provide reliable tools for monitoring germ cell differentiation, particularly in the haploid germ cell population under various physiological and pathophysiological conditions.

This study was supported by grants from the Norwegian Research Council for Science and the Humanities (NAVF), Swedish Medical Research Council (Project 3168), Rockefeller Foundation, and The Norwegian Society for Fighting Cancer.

\section{References}

Axelrod, J. \& Daly, J. (1965) Pituitary gland: enzymatic formation of methanol from S-adenosyl-methionine. Science, N.Y. 150, 892-893.

Birnbaumer, L., Yang, P.-C., Hunzicker-Dunn, M., Bockaert, J. \& Duran, J.M. (1976) Adenylyl cyclase activities in ovarian tissues. I. Homogenization and conditions of assay in Graafian follicles and corpora lutea of rabbits, rats and pigs: regulation by ATP, and some comparative properties. Endocrinology 99 , 163-184.

Braun, T. \& Dods, R.F. (1975) Development of a $\mathrm{Mn}^{2+}$ sensitive "soluble" adenylate cyclase in rat testis. Proc. natn. Acad. Sci. U.S.A. 72, 1097-1101.

Cusan, L., Gordeladze, J.O., Andersen, D. \& Hansson, V. (1981a) Characterization of protein carboxyl methylase activities in rat testis: presence of testis specific charge isomers. Archs Androl 7, 263-274.

Cusan, L., Gordeladze, J.O., Parvinen, M., Clausen, O.P.F. \& Hansson, V. (1981b) Protein carboxylmethylase and germ cell adenylyl cyclase at specific stages of the spermatogenic cycle of the rat. Biol. Reprod. 25, 915-919.

de Kretser, D.M., Sharpe, R.M. \& Swanston, I.A. (1979) Alterations in steroidogenesis and human chorionic gonadotropin binding in the cryptorchid rat testis. Endocrinology 105, 135-138.

Gagnon, C., Axelrod, J., Musto, N., Dym, M. \& Bardin, W. (1979) Protein carboxyl-methylation in rat testes: a study of inherited and X-ray-induced seminiferous tubule failure. Endocrinology 105, 1440-1445.

Gordeladze, J.O. \& Hansson, V. (1980) $\mathrm{Mn}^{2+}$-dependent adenyl cyclase $(\mathrm{AC})$ in rat testis: kinetic properties and optimalization of assay conditions. Int. J. Androl. 3, 539-552.

Gordeladze, J.O., Purvis, K., Clausen, O.P.F., Rommerts, F.F.G. \& Hansson, V. (1981) Cellular localization of the $\mathrm{Mn}^{2+}$-dependent adenylyl cyclase $(\mathrm{AC})$ in the rat testis. Int. J. Androl. 4, 172-182.
Hagenäs, L. \& Ritzen, E.M. (1976) Impaired Sertoli cell function in experimental cryptorchidism in the rat. Molec. cell. Endocrinol. 4, 25-34.

Hagenäs, L., Ritzen, E.M., Svensson, J., Hansson, V. \& Purvis, K. (1978) Temperature dependence of Sertoli cell function. In Endocrine Approach to Male Contraception, pp. 449-458. Eds V. Hansson, M. Ritzen, K. Purvis \& F. S. French. Scriptor, Copenhagen.

Jahnsen, T., Gordeladze, J.O., Haug, E. \& Hansson, V. (1981) Changes in rat testicular adenylate cyclase activities and gonadotrophin binding during unilateral experimental cryptorchidism. J. Reprod. Fert. 63, 381-390.

Jegou, B., Peake, R.A., Irby, D.C. \& de Kretser, D.M. (1984) Effects of the induction of experimental cryptorchidism and subsequent orchidopexy on testicular function in immature rats. Biol. Reprod. 30, 179-187.

Karpe, B., Plöen, L., Hagenäs, L. \& Ritzen, E.M. (1981) Recovery of testicular functions after surgical treatment of experimental cryptorchidism in the rat. Int. J. Androl. 4, 145-160.

Kerr, J.B., Rich, K.A. \& de Kretser, D.M. (1979) Alteration of the fine structure and androgen secretion of the interstitial cells in the experimentally cryptorchid rat testis. Biol. Reprod. 20, 409-422.

Kim, S. \& Paik, W.K. (1970) Purification and properties of protein methylase II. J. biol. Chem. 254, 1806-1813.

Lowry, O.H., Rosebrough, N.F., Farr, A.L. \& Randall R.J. (1951) Protein measurement with the folin phenol reagent. J. biol. Chem. 193, 265-275.

Salomon, Y., Londos, C. \& Rodbell, M. (1974) A highly sensitive adenylate cyclase assay. Analyt. Biochem. $58,541-548$.

Received 28 May 1985 